\title{
Language Kinship between Tulambatu and Tolaki Language in North Konawe
}

\section{Hanna}

Halu Ole University, Kendari

\section{Mursidin}

Haluoleo University, Kendari

\author{
Siti Nur Rochmatul Jannah
}

SMA I Oheo, North Konawe

Doi: $10.2478 / \mathrm{mjss}-2018-0009$

\begin{abstract}
This study was intended to explore the genetic relationship between Tulambatu and Tolaki languages as members of Austronesian family language, particularly those included in the branch of Malay Polynesian sub-group. They have identical and similar lexis, phonetics, as well as corresponding phonemic and different phonemes. The aims of this study were: (1) to describe the level of genetic relationship between Tulambatu and Tolakinese languages in North Konawe regency, (2) to determine the period when the two languages were separated in terms of the basic vocabulary, (3) to predict the age of Tulambatu and Tolakinese languages in North Konawe regency. Data of the study were 200 vocabulary of Tulambatu and Tolakinese languages based on Swadesh lists that have been translated by native speakers of the two languages. The study was a historical comparative linguistics research and used the Lexicostatistics technique to find evidences that explain the genetic relationship of the languages. Based on the Lexicostatistics technique, it was found that the percentage of the vocabulary relationship of Tulambatu and Tolakinese languages was $52.02 \%$. This proved that both languages are members of a sub-family of genetically similar languages (Astronesian Malayo Polinesian). In addition, it is believed that Tulambatu and Tolakinese languages were a single language 1636-1378 years ago, and they began to separate from their mother language around 379-637 AD (as of 2015).
\end{abstract}

Keywords: genetic relationship, historical comparative linguistics, Lexicostatistics technique, Tulambatu language, Tolakinese language.

\section{Introduction}

According to the local community, Tulambatu communities have existed since the Kingdom of Tulambatu with the first king named Untolipu established in Wawoheo, Takupuno. Tulambatu tribe according to local story comes from seven siblings; six brothers and a sister. The only one sister lived her life in Tulambatu, while the six brothers were scattered to other areas. The king therefore agreed to maintain the security of the village where the woman lived from any dangers. It is strongly believed by the local community that Tulambatu is struggling to develop its economic growth, but in terms of moral ethics and community behavior Tulambatu is working to maintain it. The local community believes that the king's position as a security guard always assists them by directing their way, for example if any issues appear, these are often followed by the way to figure it out with 
the direction of bamboo tree pointing it out. The contradiction of Tulambatu's name is still debatable by societies that is as the word Tulambatu by some people derived from the word cu means "down" and bamb means "stone". Therefore, Tulambatu means going down to the rock and the descent place which is called Cinutu. While other sources say that Tulambatu comes from the word culam which means "bamboo" and wacu means "stone", so Tulambatu means bamboo stone. Related to this, Adenan; Tulambatu Village Head (December 2011) reported that the origin of the Tulambatu tribes is from Bungku, Torete and Buleleng which are from Central Sulawesi , originated from the same place. The historical relics include (1) the existence of Tulambatu village since human exist, (2) grave of Tulambatu king found only in Tulambatu village, (3) bamboo stone consisting of 7 stems which have not been developed for thousands of years, (4) cave of skull which existed since thousands years ago, (5) the discovery of some artifacts such as ceramics estimated from China (6) large trees that have relics of paper money, metal which has not been destroyed until now. Currently in Southeast Sulawesi, Tulambatu tribe can be found in three sub-districts in North Konawe, such as in Oheo, Langgikima, and Wiwirano. Tulambatu tribe which occupies one village only in each sub-district is Landawe Bawah village in Oheo district, Landawe Atas in Wiwirano, and Atambakua village in Langgikima.There are several hypotheses about the Tulambatu people. Firstly, Tulambatu people are from Portuguese. This is because their high posture can reach approximately 2 meters tall, so some people call them giant person. In addition, they are also blueeyed and white and a bit reddish skinned like the Portuguese. Secondly, if seen from the aspect of the relics in the caves where they lived when the ceramics came from China, the hypothesis says that Tulambatu people may also come from China. These assumption are still mistery.

Indonesian is a plural nation, consisting of various kinds of tribes spreading out across the country. Each tribe has its own language to communicate, both ethnic and interethnic. Languages originating from one parent origin (cognate) have a kinship relationship in the past. This is indicated by the equation of form and meaning which is a reflection of the history of the same heritage (Keraf, 1996: 34). Indonesia has a wide range of ethnic or ethnic groups spreading across the country, so that each ethnic language has its own language used in both ethnic and inter-ethnic communication. According to Parera (1991: 187) there are 5445 languages in the world. Of that number some languages are in Indonesia. Summer Institute of Linguistic (2006) data shows 741 local languages in Indonesia. Related to this Southeast Sulawesi for example is one of the provinces in Indonesia that also has a variety of ethnic as well as in terms of language. The local language used in Southeast Sulawesi is included in the Bungku-Laki group. The results of languages mapping that have been done by Language Mapping Team Office of Southeast Sulawesi Province in 2006 found nine languages of indigenous peoples in Southeast Sulawesi, namely 1) Tulambatu language; 2) Ciacia language; 3) Kulisusu language; 4) Lasu Kamaru language; 5) Moronene language; 6) Muna language; 7) Pulo language; 8) Tolaki language; 9) and Wolio language. Summer Institute Linguistic (SIL) (2006) study found a different result where they discovered 19 regional languages in Southeast Sulawesi, i.e. 1) Cia-Cia language; 2) Kambulawa language; 3) Kamaru; 4) Kioko language; 5) the language of Kodeoha; 6) Kulisusu language; 7) Kumbewaha language; 8) Lasal language; 9) Liabuku language; 10) Moronene language; 11) Muna language; 12) Pancana language; 13) Rahambuu language; 14) Taloki language; 15) Tolaki language; 16) language of the Southern Iron Worker; 17)language of the Northern Ironman; 18) Wawonii language; And 19) Wolio language.

\section{Review of Literature}

In other literatures, Mead (1995) examines the kinship of languages within Southeast Sulawesi and partly in the Central Sulawesi region by using lexicostatistics method. According to Mahsun, (1995: 115) "Lexicostatistics is a method of grouping the language performed by calculating the percentage of cognate devices (kin)". According to Keraf, (1984: 121) Lexicostatistics is a technique in the languages grouping that are more likely to dominate the observation of words (lexicon) statistically, then to try to set the grouping percentage which equalizes the equality and the difference of a language with other languages.

The language kinship and mapping of regional languages in Southeast Sulawesi province 
based on lexicostatistics calculations, isogloss file compilation, isoglos calculation, and dialectometry, indicates five language groups, namely; (1) groups of Tolaki languages consisting of three subgroups, namely; Tolaki subgroup, the Wawonii-Kulisusu subgroup, and the MoreneneRahantari subgroup, (2) the Muna-Cia-cia languages group consisting of four subgroups, namely; Muna subgroup, Cia-cia subgroup, Kumbewaha subgroup, and the Todangan-Kambowa subgroup, (3) groups of Pulo languages consisting of only one subgroup, namely; the subgroup of Pulo Kapota-Tomia-Kaledupa-Binongko, (4) Bugis language group consisting only of one sub-group, namely; Bugis Lamunde, and (5) Java language groups consisting of only one subgroup, namely; Java Bangun Sari (Lauder,2000).

\subsection{Theoretical Basis}

The term evolution is more popularly used in the field of Biology which means the process of changing the shape of an existing organism, in the long term developing naturally from the simpler form into a more complex final form with various variations, modifications, and characteristics of an offspring. The hereditary theory with modification through natural selection has a universal value (Darwin, 2002). In fact, linguists have been using this concept first. Sir William Jones (1786) suggests that Sanskrit, Latin, Gothic, and Celtic languages belong to one family and derive from the same proto language that is no longer to be found. This is the basis for knowing the Indo-European family and reconstructing the form. Therefore, the notion of change in form (transformism) is first used in linguistics when compared to the science of Biology. This phenomenon occurs because the language is more quickly changed and easily observed when compared to biological species (McMahon, 1999). Language and species are equally transformed, leading to the emergence of the classification illustrated by the kinship tree. Biological languages and populations share two common characteristics: (1) the structure can be passed from one generation to the next, and (2) the isolated variations develop independently of each other (Lass, 1990). In Biology, genetic inheritance mechanisms provide an opportunity for parent properties to decline their children, whereas genetic divergence, sometimes is caused by geographical isolation, then it leads to the independence of variation forms that can eventually be called species. As in Biology, it reduces the genetic properties of the mother tongue to derive languages. The form of isolation of variations caused by geographical distance or sociopolitical boundaries provides an opportunity for the development of locally different variations. (see in appendix 1).

\subsection{Proto Bungku-Tolaki}

The language developed in Southeast Sulawesi is the Bungku-Tolaki language group (Astronesian, Western Malayo-Polynesian). There is not much written information about the Bungku-tolaki community except historical stories told from the memories of the living people at that time. Only a few traces of the abandoned history like those in the Buton sultanate found which later a concern on the mainland of Sulawesi Southeast. Dutch in 17th century was already in mainland of Indonesia and then in the 19th century their ship was in mainland of Southeast Sulawesi (Vosmaer, 1839). For about 70 years, the area was targeted by outsiders, scientists (Giglioli, 1874, Sarasin 1896, Sarasin \& Sarsin 1903, Elebert 1911-1912) and so on (Van de Hart, 1853; Bosscher \& Matthjissen, 1853; Uhlenbeck , 1861).The Bungku people (also called "To Bungku") live in the areas of North Bungku, Central Bungku, South Bungku, and Menui, in Poso district, Central Sulawesi province. They also exist in some other areas of Sulawesi. Furthermore, the Bungku people are divided into sub-groups such as Lambatu, Epe, Rete, and Ro'Uta. The language used by Bungku people is Bungku (often called Bungku Laki), that is in the same language group with various Filipino languages.

The Bungku-Tolaki Proto, or Proto Bungku-Tolaki, is the Bungku-Tolaki old language, spoken in Southeast Sulawesi, Indonesia, in the past to the present, but has been changed and become somewhat different from the current Bungku-Tolaki language because it has been separated for so long into several dialects. Proto Bungku-Tolaki belongs to the Austronesian Proto MalayoPolynesian, Celebic and is classified into the family of Bungku-Tolaki family. Based on the map it 
can be seen that the spread of Bungku-Tolaki occupies most of Southeast Sulawesi region. Proto Bungku-Tolaki is bordered on the north by the Kaili-Pamona group, in the west by South Sulawesi group, in the south by the Muna-Buton group, and in the west by the Banda sea. Mead $(1999 ; 11)$ suggests that the Bungku-Tolaki region refers to fifteen languages based on lexicostatistics synchronic analysis, divided into three subgroups: first, the subgroup of Bungku-Moronene, Taloki, Kulisusu, Wawonii, and Bungku. Second, the Mori sub-group consists of Bohonsuai, Mori Bawaah, Padoe, Mori Atas, and Tomadino. Third, the Tolaki Subgroup consists of Waru, Tolaki, Rahambuu, Kodeoha. Of the three sub-groups some are distributed into several scattered dialects.

The reconstruction of proto language rests on two hypotheses, namely connectedness and order (Jeffers and Lehiste, 1979: 17; Hock, 1988: 567). The common characteristic of this connotation hypothesis is the similarity of the linguistic form. One of the most reliable features is the similarity of form and meaning of words. Words that have similar or identical forms and meanings are called cognate sets (not as loans, coincidences, or tendencies of the universe), but hypothesized as the inheritance of the same origin. The regularity hypothesis consists of the systematic and disordered changes in sound in derived languages. A segment of the proto language sounds that are inherited through the vocabulary as it changes regularly in a derived language.The search for the inherited elements of language are lexical, phonological, morphological, and syntactic. In the comparative study, lexical and phonological levels are more commonly used as a basis for determining kinship and reconstruction of a cognate language for the following reasons. First, through lexical reconstruction, the information about culture, history, social life, and geographical facts of a linguistic society can be obtained. Second, the most successful reconstruction of comparative historical study is at the phonological level due to various factors, namely (a) a segment or phonological element is the smallest element in a language, thus it is easier to understand, (b) It is easier to find relevant facts when compared to other levels, (c) sound problems have been extensively studied in linguistic studies, so it has been a very well established study, (d) sound changes are regular and may indicate the relationship between them (Hock, 1988: 573 and Gordon, 2002: 59).

The core vocabulary on the other hand includes a vocabulary that is as old as humans and more difficult to change than any other vocabulary. There are several opinions about the percentage range of vocabulary changes which is relative to retention. Swadesh, (1952), Hockett (1963), and Dyen (1975) argue that vocabulary changes generally can reach between $19 \%$ in every thousand years or are able to survive between $81 \%$; Crowley (1983) argues $80 \%$, while Keraf (1985: 124) argues $80.5 \%$. That is why the vocabulary is said to be constant all the time. The quantitative evidence is used as a basis for grouping in the early stages of a language for the purpose of obtaining the percentage of vocabulary relatives calculated using lexicostatistics, and computing the periods of each language using glotocronology (Dyen, 1978 and Swadesh, 1972).

\subsection{Language Kinship Level}

The relation of interlanguage-related kinship in comparative study can basically be proved on the basis of inherited elements of the language of origin or protobahasa (Hock, 1988). The concept of the original language or the actual proto language is not a real form of language, but a form that is constructed or re-assembled as a description of a language's past. In other words, this concept is a theoretical idea that is designed in a very simple way to connect the systems of a common language by using a number of rules (Jeffers and Lehiste, 1979, Bynon, 1979: 71). Linguistic facts in the form of order and correspondence found in the languages of the relatives show evidence of mutual consciousness inherited from the same ancestor (Bynon 1979: 47).

\subsection{Lexicostatistics}

Keraf (1990: 123) mentions four basic assumptions of lexicostatistics as follows (1) some of the vocabulary of a language is very difficult to change when compared to other parts (2) the basic vocabulary retention is constant throughout the ages, (3) the basic vocabulary changes in all languages are the same, (4) if the percentage of two kin languages (cognate) is known, then 
separation time of the two languages can be calculated. Lexicostatistics is one of the language or dialects grouping techniques that emphasize on the statistical calculations of words to know the number of similarity of comparable relatives' words (Grimes 1987 in Mead, 1999). Keraf (126: 1990) points out that to apply the four basic lexicostatistical assumptions the necessary steps are (a) to collect the basic vocabulary of the related language (b) to set which pairs of the two languages are the word relatives, (c) to establish the words of the relatives (cognates) of the languages under investigation. A pair of words will be declared to be related if they meet one of the following conditions: (1) the pair is identical, (2) it has phonemic correspondence, (3) it has phonetic similarities, (4) it also has different phoneme. To calculate the percentage of kinship based on the relatives words based on the percentage criteria set out previously to determine the level of kinship by using the formula below:

$\mathrm{C}=\mathrm{K} / \mathrm{G} \times 100 \%$

Where: $\mathrm{C}=$ cognate or kin, $\mathrm{K}=$ the number of vocabulary relatives and, $\mathrm{G}=$ number of gloss

To calculate the age or time separating between the two languages.

Calculates the error term to determine the possibility of a more precise separation time with the following formula:

$W=\log C /(2 \log r)$

Where:

$\mathrm{W}=$ time separation in thousands (millennium) years ago, Log $=$ logarithm of, $\mathrm{C}=$ presentation of identical and similarities, and $R=$ constant retention or percentage in 1000 , or also called index.

(Keraf, 1984: 130)

The calculation of error run

It is unlikely that the separation between two languages occurs within a given year, but occurs gradually, and then a period of separation must take place. For that purpose certain calculations should be held to avoid such errors since statistical techniques are required to calculate the error run. To calculate the length of the error it should be remembered that standard deviation is usually used, i.e. $70 \%$ of the estimated truth. The default error is calculated with the following formula:

$S=\sqrt{ }((C(1-C)) / n)$

Information:

$\mathrm{S}=$ deviation standard in the relative word percentage, $\mathrm{C}=$ percentage of relatives, and $\mathrm{N}=$ number of comparable words (both relatives and non-relatives)

(Keraf, 1984: 132)

The calculation of time separation after the level of error run has been identified.

After calculating the error run using the above formula, it is necessary to recalculate the separation time by the following formula:

$\mathrm{W} 1=(\log (C+\sqrt{ }((C(1-C)) / n))) /(2 \log r)$

Information:

W1 = the separation time length in thousands of years (after calculating error run).

After that the time obtained after calculating the run of error, reduced by the first amount of time (before calculating the run of error) with the formula: W - W1

\section{Research Method}

This comparative historical linguistic study uses lexicostatistics method by grouping the language performed by calculating the percentage of cognate devices. The research was conducted in Landawe and Wiwirano in Oheo of Konawe Utara region by applying translation and record techniques based on the informant information which has been selected based on the predetermined criteria. It is more likely to prioritize the observation of words (lexicon) statistically, to attempt to establish the grouping based on the percentage of similarities and differences of a language with other languages and also to be able to classify kinship between two or more languages by comparing the vocabulary and the similarities exist.

The basic vocabulary consists of 200 words (see appendix 2) composed by Morris Swadesh. The vocabulary covers the cultural vocabulary of both languages based on the following categories, (a) 
body parts (b) pronouns, greetings, and references (c) kinship system, (d) village life and community (e) house and its parts (g) equipment and supplies (h) food and drink (i) growth, parts, fruit, and processed products (j) animal and its parts $(k)$ time, season, nature, things, nature and direction (I) motion and work (m) war, nature, and color (n) Illness (o) clothing and jewelry, and (p) numbers and sizes. After the 200 basic vocabulary was determined, the lexicostatistics technique then was undertaken by following steps; (1) collecting the basic vocabulary of relatives, (2) determining which pairs of the two languages are related (3) calculating the age or time separating the two languages (4) calculating the error run time to determine the possibility of faster split time. The data analysis performed was a basic method to proof the basic assumptions followed by lexicostatistics formulas as mentioned previously.

\section{Research Findings and Discussion}

\subsection{The words kinship between Tulambatu and Tolaki Language}

One of the focuses in this research is to know the level of kinship occured between Tulambatu and Tolaki language, before the lexicostatistics calculation is done to know the language separation time, the age and the split time of those languages, the researcher needed to ensure that there are some words which were excluded from the calculation, for instance, blanks, loanwords, and related and unrelated words categorization. Tulambatu and Tolaki languages are based on a related vocabulary. Based on data obtained from informants, the authors present a comparison in table 3 to see the related words between Tulambatu and Tolaki language.

\subsection{Language Kinship of Tulambatu and Tolaki Language}

After classifying related and unrelated word pairs in each pair of the language, then the kinship level will be determined after first calculating the percentage of kinship based on identical word kinship indicator, phonemic correspondence, phonetic resemblance, and different phoneme. After establishing the words of the relatives with the procedure as mentioned above, it can be determined the amount of kinship percentage between the two languages. In the table it is explained that in order to establish the word relatives of the languages under investigation, there are procedures that can be used as indicators for determining the word relative i.e. determining the pairs of identical words, whether the word pairs have phonemic correspondences, have phonetic resemblances and have a different phoneme.

The categories are determined based on Keraf's (1984: 128) theory which states that a word pair will be revealed to a relative when one of the provisions of (a) the pair is identical, (b) the pair has phonemic correspondence, (c) the pair has phonetic similarity, or (d) it has one different phoneme. In this study the determination of the word relatives is based on four indicators following Keraf's theory which can be explained as follows (See in appendix 3 )

\subsubsection{The word pairs are identical}

One of the provisions in defining the word pair as a relative is that the word pair has identical similarities. Identical in this case is that the word pair has the exact same shape, sound and meaning (See in the appendix 4)

\subsubsection{The pair has a phonemic correspondence}

If phonemic changes between the two languages occur reciprocally and regularly and their frequency is high, a balanced form between the two languages and the phonemically corresponding word pair is a word pair having a relationship between two languages based on the phonemephoneme position and the same meaning of both languages are compared, it can be said that the word pair is related. 
Table 1: Pairs of Words that Have Phonemic Correspondence

\begin{tabular}{|c|c|c|c|}
\hline No & Cognate, Indonesian language & Tulambatu Language & Tolaki Language \\
\hline 1 & Anak & ana ate & o ana \\
\hline 2 & Apa & Hawaa & Hawo \\
\hline 3 & Baju & Lambu & Babu \\
\hline 4 & Berjalan & Lumela & Lomolako \\
\hline 5 & Bunuh & Hapusu & Pepatei \\
\hline 6 & Hapus & Moito & Napusui \\
\hline 7 & Hitam & Motea & me'eto \\
\hline 8 & Keras & Roana & Mana \\
\hline 9 & Kanan & Melue & Melewe \\
\hline 10 & Lebar & Melaa & Mendaa \\
\hline 11 & Panjang & Luwuako & Wuluako \\
\hline 12 & Semua & Toli & Tiolu \\
\hline 13 & Telur & Purio & Pupurii \\
\hline 14 & Tiup & & \\
\hline
\end{tabular}

Gloss 'baju', phoneme correspondence occurred on / I- b- / and / -m- - - - I

Tulambatu Language

Tolaki Language

Gloss 'keras', phoneme correspondence occurred on/ -e- -o- / and / - ø- -h- /

Tulambatu Language

Tolaki Language $/ \mathrm{m} /, / \mathrm{o} /, / \mathrm{t} /, / \mathrm{e} /, / \varnothing /, / \mathrm{a} /$ $/ \mathrm{m} /, \mathrm{lo} /, \mathrm{tt} /, \mathrm{lo} /, \mathrm{h} /, \mathrm{la} /$

Gloss 'lebar', phoneme correspondence occurred on/ -u- -e- / / - $-\sim$ w- /

Tulambatu Language

Tolaki Language $/ \mathrm{m} /, \mathrm{e} /, / \mathrm{l} /, \mathrm{lu} /, \mathrm{l}$ ø /,/e/ $/ \mathrm{m} /, \mathrm{e} /, \mathrm{l} /, \mathrm{e} / \mathrm{e}, \mathrm{w} /, \mathrm{e} /$

Gloss 'semua', phoneme correspondence occurred on/ I- w- / / -w - I- /

Tulambatu Language

Tolaki Language $/ \mathrm{l} /, \mathrm{u} /, / \mathrm{w} /, / \mathrm{u} /, \mathrm{la} /, \mathrm{lk} /, / \mathrm{o} /$

\section{,}

Gloss 'hapus', phoneme correspondence occurred on/h- n- / / - ø - i- /

Tulambatu Language

Tolaki Language $/ \mathrm{h} /, \mathrm{a} /, / \mathrm{p} /, / \mathrm{u} /, \mathrm{s} /, / \mathrm{u} /, /$ ø / /n/, /a/,/p/, /u/, /s/, /u /,/i/

\subsubsection{Phonetic resemblance}

If a pair of words cannot be proved to contain phonemic correspondence, but the pair appears to be phonetically similar in the same articulator position, the couple can be regarded as a relative word.

Table 2. The Data of word pairs that have phonetic similarities

\begin{tabular}{|c|c|c|c|c|}
\hline NO & Cognate, Indonesian Language & Tulangbatu Languague & Tolaki Language & Phonetics defects \\
\hline 1 & Batu & watfu & Batu & $w-\beta, t-t$ \\
\hline 2 & Ikat & Monkoo & mo'ongo & $\mathrm{k}-\mathrm{g}$ \\
\hline 3 & Kutu & kutfu & Kutu & $t 5-\mathrm{t}$ \\
\hline 4 & Leher & Boronko & Woroko & $b-w$ \\
\hline 5 & Makan & Monkaa & Monga & $\mathrm{k}-\mathrm{g}$ \\
\hline 6 & Perempuan & tyina & Tina & $t 5-\mathrm{t}$ \\
\hline 7 & Perut & tia & Tia & $t-t$ \\
\hline 8 & Punggung & Bungku & Bunggu & $\mathrm{k}-\mathrm{g}$ \\
\hline 9 & Tajam & Montaso & Mongaso & $t-g$ \\
\hline 10 & Tikam & tinobo & Tobo & $t-\mathrm{t}$ \\
\hline 11 & Tua & motfu'a & Motuo & $t-t$ \\
\hline
\end{tabular}




\subsubsection{Different phoneme}

If in one word pair there is a difference of one phoneme, but it can be explained that the difference occurs because of the influence of the environment it enters, whereas in other languages the influence of that environment does not change its phoneme, then the pair can be defined as the word of kin.

Table 3. The Data of Word Pairs Which Have One Different Phoneme

\begin{tabular}{|c|c|c|c|c|}
\hline $\mathrm{NO}$ & Cognate, Indonesian Language & Tulangbatu Languague & Tolaki Language & Fonem Differences \\
\hline 1 & Angin & o pue & Pua & $/ \mathrm{e} / \rightarrow \mathrm{la} /$ \\
\hline 2 & Baik & Meampo & Meambo & $/ \mathrm{p} / \rightarrow / \mathrm{b} /$ \\
\hline 3 & Bapak & Tama & o ama & $\mid \varnothing / \rightarrow / a /$ \\
\hline 4 & Berapa & opia & Opio & $/ \mathrm{a} / \rightarrow / \mathrm{O} /$ \\
\hline 5 & belah (mem) & mowo'a & Mowota & $\mid \varnothing / \rightarrow / \mathrm{a} /$ \\
\hline 6 & Benar & Tekona & Tekono & $/ \mathrm{a} / \rightarrow / \mathrm{o} /$ \\
\hline 7 & Dengar & Podea & Podeai & $/ \varnothing / \rightarrow / \mathrm{i} /$ \\
\hline 8 & Dua & Rua & Oruo & $/ \mathrm{a} / \rightarrow / \mathrm{o} /$ \\
\hline 9 & Hidup & Tora & Toro & $\mid \mathrm{a} / \rightarrow / \mathrm{o} /$ \\
\hline 10 & la & laa & le & la/ $\rightarrow / \mathrm{e} /$ \\
\hline 11 & Kaki & Karu & Kare & $/ \mathrm{u} / \rightarrow / \mathrm{e} /$ \\
\hline 12 & Kecil & Mohewa & Mohewu & $\mid \mathrm{a} / \rightarrow / \mathrm{u} /$ \\
\hline 13 & Kelahi (ber) & Mekidu & Metidu & $/ \mathrm{k} / \rightarrow / \mathrm{t} /$ \\
\hline 14 & Licin & Molore & Moloro & $\mathrm{le} / \rightarrow \mathrm{lo} /$ \\
\hline 15 & Lima & Lima & Limo & $/ \mathrm{a} / \rightarrow \mathrm{lo} /$ \\
\hline 16 & Ludah & Inii & Eni & $/ \mathrm{i} / \rightarrow \mathrm{le} /$ \\
\hline 17 & Lurus & Mondulo & Mindulo & $/ \mathrm{o} / \rightarrow / \mathrm{i} /$ \\
\hline 18 & Peras & pio'o & Pioi & $/ \mathrm{o} / \rightarrow$ /i/ \\
\hline 19 & Potong & Pole & Polei & $|\varnothing| \rightarrow / \mathrm{i} /$ \\
\hline 20 & Satu & o asa & o aso & $/ \mathrm{a} / \rightarrow \mathrm{lo} /$ \\
\hline 21 & Tanah & Wita & Wuta & $/ \mathrm{i} / \rightarrow / \mathrm{u} /$ \\
\hline 22 & Ular & Saa & Sao & $/ \mathrm{a} / \rightarrow \mathrm{lo} /$ \\
\hline
\end{tabular}

When in one word pair there is a difference of one phoneme, but it can be explained that the difference is due to the influence of the environment it enters, then the pair can be defined as the word of kin.

For example in 'baik' gloss, phoneme / $\mathrm{p} /$ in Tulambatu is different from phoneme / b / in Tolaki language.

meampo $\rightarrow$ meambo

For gloss 'angin' phoneme /e/ in Tulambatu is different from phoneme /a/ in Tolaki language.

pue $\rightarrow$ pua

After establishing the relative's words with the procedure as mentioned above, it can be determined the percentage of the two languages compared. Based on the word kinship comparison between Tulambatu and Tolaki languages, the results obtained are presented in Table 5.

Table 4. Accumulation of Tulambatu and Tolaki Language

\begin{tabular}{|c|l|c|}
\hline No & Kinship Indicator & Number \\
\hline 1 & Identical & 55 \\
\hline 2 & Having a phonemic correspondence & 14 \\
\hline 3 & Phonetics defects & 12 \\
\hline 4 & One different phoneme & 22 \\
\hline & Total related words & 103 \\
\hline
\end{tabular}

The percentage of the word relatives is calculated from the pairs of 200 words excluding some 
pairs which are categorized as loanwords. From 200 words of Tolaki and Tulambatu languages, there were two loanwords that have no pair or meaning in one of the regional vocabulary so that it can be obtained by a pair of twenty-one words of relatives in calculation. Of the 198 pairs of words that are relatives based on four kinship indicators which resulted 103 pairs of related words and 95 unrelated word pairs.

After observation, from 103 pairs of words, the number of identical word pairs between Tolaki and the Tulambatu languages is 55 word pairs or $27.8 \%$ said as relatives and word pairs that have phonemic correspondence are 15 pairs of words or $7.6 \%$ said as relatives. In addition phonetic similarity is also owned by eleven pairs of words or $6.1 \%$ said as relatives and pairs of words that have one different phoneme are 22 pairs of words or $11.1 \%$ said as relatives.

The calculation of the word relatives is undertaken by applying the below formula:

$$
\begin{aligned}
& \text { C }=\frac{K}{G} \times 100 \% \\
& =\frac{103}{198} \times 100=52,02
\end{aligned}
$$

After obtaining the kinship percentage of Tolaki and Tulambatu language, determining the classification of the kinship level of both languages is considerably important. Based on the Keraf's theory (1984: 135) related to language kinship, Tolaki and Tulambatu language relation percentage is $52.02 \%$, Tolaki and Tulambatu languages are in one language family. After knowing the kinship percentage of Tulambatu and Tolaki languages, it is then easier to calculate the age and separation time of both languages by drawing attention to two important things from the calculation of the word of kin which is 52.02 said as relatives and 198 pairs of words available.

\subsubsection{Language Age separating Tulambatu and Tolaki Language}

After the level of kinship, the formulation of the second problem in this study is to seek the age of language separation. Keraf (1990: 133) mentions the term language age, unlike Parera (1991: 8) which calls the time of separation, but basically this term has no different meaning. The language age or language separation time is the time of the separation of a pair or multiple languages from the parent language, in other words the time of the beginning of the new language, so that it will refer to the age of the language. Since language separation requires a long process, separation time or language separation is impossible to write in a given year, but will be written in thousands of years. In accordance with the explanation in the research method, the calculation of separation age is done by the following steps:

Calculating the amount of separation time

Table 4. Logarithm Table

\begin{tabular}{|c|c|c|c|c|c|c|c|c|c|c|}
\hline $\mathrm{N}$ & 0,00 & 0,01 & 0,02 & 0.03 & 0,04 & 0,05 & 0,06 & 0,07 & 0,08 & 0,09 \\
\hline 0,1 & $-2,303$ & $-2,207$ & $-2,120$ & $-2,040$ & $-1,966$ & $-1,897$ & $-1,833$ & $-1,772$ & $-1,715$ & $-1,661$ \\
0,2 & $-1,609$ & $-1,561$ & $-1,514$ & $-1,470$ & $-1,427$ & $-1,386$ & $-1,347$ & $-1,309$ & $-1,272$ & $-1,238$ \\
0,3 & $-1,204$ & $-1,171$ & $-1,139$ & $-1,109$ & $-1,079$ & $-1,050$ & $-1,022$ & $-0,994$ & $-0,968$ & $-0,942$ \\
0,4 & $-0,916$ & $-0,892$ & $-0,868$ & $-0,844$ & $-0,821$ & $-0,799$ & $-0,777$ & $-0,755$ & $-0,734$ & $-0,713$ \\
0,5 & $-0,693$ & $-0,673$ & $-0,654$ & $-0,635$ & $-0,616$ & $-0,598$ & $-0,580$ & $-0,562$ & $-0,545$ & $-0,528$ \\
0,6 & $-0,511$ & $-0,494$ & $-0,478$ & $-0,462$ & $-0,446$ & $-0,432$ & $-0,416$ & $-0,400$ & $-0,368$ & $-0,371$ \\
0,7 & $-0,357$ & $-0,342$ & $-0,329$ & $-0,315$ & $-0,301$ & $-0,288$ & $-0,274$ & $-0,261$ & $-0,248$ & $-0,236$ \\
0,8 & $-0,223$ & $-0,211$ & $-0,198$ & $-0,186$ & $-0,174$ & $-0,163$ & $-0,151$ & $-0,139$ & $-0,128$ & $-0,117$ \\
0,9 & $-0,105$ & $-0,094$ & $-0,083$ & $-0,073$ & $-0,062$ & $-0,051$ & $-0,041$ & $-0,030$ & $-0,020$ & $-0,010$ \\
\hline
\end{tabular}

Known $\mathrm{C}=52,02 \%$ to 0,520 , and $r$ (retention ) $=80,5 \%$ to 0,805 .

$\mathrm{W}=\frac{\log \cdot C}{2 \log r}$

To obtain the value of logarithm of 0.520 , first searched the logarithm of row 0,5 and column 0,02 .

So based on logarithm table, the value of log. 0.520 is -0.654

Similarly, the same thing is done to find the logarithm of 0.005 in searching the log.R which is 
$0.805 ;$ Log. $80=-0,223$

Log. $81=-0,211$

Difference $=-0.012: 2=-0.006$

Thus log. 0805 is -0.217 i.e:

$-0,211+(-0,006)=-0,217$

$-0,223-(-0,006)=-0,217$

After log.C and log $r$ are known, the age of the Tulambatu language and Tolaki language are:

$\mathrm{W}=\frac{\log \cdot C}{2 \log r}$

$W=\frac{\log .0,520}{2 \log 0,805}=\frac{-0,654}{2(-0,217)}=\frac{-0,654}{-0,434}=1,507$

$W=1,507 \times 1000$ years $=1507$ years

Testing the error run

Having known the calculation of initial separation time, then the next step is to calculate the error term, in accordance with the formula used. The value obtain for the error run is 0.03

$$
\begin{aligned}
& S=\sqrt{\frac{C(1-c)}{n}} \\
& S=\sqrt{\frac{0,654(1-0,654)}{198}} \\
& S=\sqrt{\frac{0,654 \times 0,346}{198}}=\sqrt{\frac{0,226284}{198}}=\sqrt{0,001142848} \\
& S=0,034 \text { (rounded to } 0,03 \text { ) }
\end{aligned}
$$

To calculate the amount of separation time after the calculation of error term is finished.

The result of this standard error is 0.03 summed with the percentage of relatives to get new $C$ that is $0,520+0,03=0,55$. Having obtained this new $C$, again calculating the separation time by using the following formula:

$$
\mathrm{W}=\frac{\log . \mathrm{C}}{2 \log r}
$$

To obtain a log value.0,55 in logarithm table, it can be seen at line 0,5 and column 0,05 so that the obtained log value $0,55=-0,598$

Similarly, the same thing is done to find the logarithm of 0.005 where it has been obtained before to find the log value i.e. $0.805=-0.217$ (step 1).

So the separation time after the calculation of error term is:

$$
\begin{aligned}
& W_{1}=\frac{\log . C}{2 \log r} \\
& W_{1}=\frac{\log .0,55}{2 \log 0,805}=\frac{-0,598}{2(-0,217)}=\frac{-0,598}{-0,434} \\
& W_{1}=1,378 \\
& \text { So, } 1,378 \times 1000=1378 \text { years. }
\end{aligned}
$$

Finally, the separation time of both languages is

$\mathrm{W}-\mathrm{W}_{1}$ means that, 1507 years -1378 years $=129$ years

\section{Discussion}

Based on the description of the results indicating the comparison between Tulambatu and Tolaki languages, the descriptions of kinship and language age between Tulambatu and Tolaki languages will be described as well. The description of Tulambatu and Tolaki Languages is based on the calculation of the kinship level percentage described earlier. Based on the percentage, it is known that from the 200 basic vocabulary given to the informants to be translated, two word pairs are excluded from the research because one of the pairs is loanwords and has no meaning in the language. The uncounted word pairs include /meat/ and /nails/ which are categorized as loanwords. The unmentioned word count was then eliminated to obtain a couple of calculated word pairs. After the analysis finished, 95 unrelated pairs of words and 103 related pairs of words were obtained. Known from 103 basic vocabulary, there are 55 related to identical categories, fifteen words are 
having phonemic correspondences, eleven related words are phonetic similarities, and twenty-two related words are caused by different phoneme.

In addition, regarding to the age of Tulambatu and Tolaki languages, the researchers first calculated the initial separation time of Tulambatu and Tolaki languages in accordance of predetermined formula. The result indicates that the percentage of kinship between Tulambatu and Tolaki language is $52,02 \%$ and the $r$ (retention) value is $80,5 \%$. The results obtained in the initial separation time calculation are 1507 years. Both languages were estimated to begin to split from their mother tongue approximately 508 AD (calculated from 2015).

Furthermore, when the initial separation time has been counted, the researchers then decide the error term by applying pre-determined formula. The result is 0.03 . Moreover, the error term is implemented to the recalculation process which obtains 1378 years as the result of separation time. Finally, the researchers reduce the initial separation time $\mathrm{W}$ by the time separated after the calculated error term (W1), 1507 years -1378 years $=129$ years.

Based on Keraf's theory, the separation of two languages is unlikely to happen at any one time, but in a certain period of time (1990: 131). In that period there was an accumulation of differences between the two languages, which grew so steadily that slowly but surely marked the separation between the two languages. The age or split years of Tulambatu and Tolaki languages can be expressed as follows:

Tulambatu and Tolaki languages split 1507 years \pm 129 years which means between $(1507+$ $129)$ years and (1507 - 129) years ago. The Tulambatu and Tolaki languages were the only language 1636-1378 years ago. The Tulambatu language and Tolaki language are thought to begin to separate from their mother tongue approximately at 379-637 AD (calculated in 2015).

\section{Conclusion and Recommendation}

Based on the theoretical description proposed on lexicostatistics analysis providing the comparison between Tulambatu and Tolaki languages, the writer concludes that the percentage of $52.02 \%$ has been calculated, which if rounded to $52 \%$ belongs to the language family category. Tulambatu and Tolaki language split 1507 years \pm 129 years, which means that it exists between $(1507+129)$ years and (1507 - 129) years ago. In other words, Tulambatu and Tolaki languages were single languages from 1636-1378 years ago. Tulambatu language and Tolaki language are thought to begin to separate from their mother tongue approximately at 379-637 AD (calculated in 2015).

Based on the above conclusions, the authors suggest the government to keep the importance of language function in Indonesia. Besides, it is desirable to pay attention to languages that are almost extinct. Finally, the researchers strongly recommend the next researcher to conduct more deeply and more specifically similar study using synchronic and diachronic language analysis. This aims at providing education and information resources for those who will conduct similar research to explore the kinship of languages in Indonesia, especially in Southeast Sulawesi.

\section{References}

Blust, R. A. (1974). Eastern Austronesian: a note. Working Papers in Linguistics, , 6(4):101-107. . (1977). The Proto-Austronesian pronouns and Austronesian subgrouping. Working Papers in Linguistics, $9(2): 1-15$.

Chaer, A. (2003). Linguistik Umum. Jakarta: Rineka Cipta.

Dyen, I.. (1965). A lexicostatistical classification of the Austronesian languages, International Journal of American Linguistic,s 25.

Esser, S.J. (1938). "Talen". Dalam Atlas van tropisch Nederland, 9-9b. Amsterdam: Koninklijk Nederlandsch Aardrijkskundig Genootschap.

Edwards, O.(2012). A Research: Grammatical Functions in Tolaki. Canberra: The Australian National University.

Greenhill, S.J., Blust. R, \& Gray, R.D. (2008). The Austronesian Basic Vocabulary Database: From Bioinformatics to Lexomics. Evolutionary Bioinformatics, 4:271-283. Retrieved in May 2014 from http://language.psy.auckland.ac.nz/austronesian/language.php.

Grimes, C.E. 1990."Notes on Blust 1990".(Mimeo.) 
Hanna. (2012, January 28). Landawe Kerajaan Tertua Yang Terlupkan, Bahasa Asli Yang Terpinggirkan. Surat Kabar Harian Kendari Pos.

Hanna. (2012). Bahasa Tulambatu di Sulawesi Tenggara (Dulu, Kini dan Akan Datang)_. Kyoto : Hokato Publishing Inc.

Keraf. G. (1996). Linguistik Bandingan Historis. Jakarta: Gramedia Pustaka Utama.

Kridalaksana. H.. (2002). Kamus Linguistik. Jakarta: PT Gramedia.

Bellwood, P., et.al. (1995). The Austronesians: historical and comparative Perspectives. Canberra: Research School of Pacific and Asian Studies, The Australian National University.

Mahsun. (1995). Dialektologi Diakronis. Yogyakarta: Gadjah Mada University Press.

Mattews, P.H. (1974). Morphology: An Introduction to Theory of Word Structure. Cambridge: Cambridge University Press.

Mead, D. (1998). Proto-Bungku-Tolaki: Reconstruction of its Phonology and Aspects of its Morphosyntax. Rice University: Ph. D.thesis.

Mead, D. (1999). The Bungku-Tolaki languages of South-Eastern Sulawesi, Indonesia. Pacifc Linguistics D-91.

Mills, R. F. (1975). Proto-South Sulawesi and Proto-Austronesian phonology.PhD dissertation, University of Michigan. Ann Arbor: University Microfilms International.

Nida, E. A. (1963). Morphology: The Descriptive Analysis of Words. Ann Abror: The University of Michigan Press.

Parera, J. D. (1986). Studi Linguistik Umum dan Historis Bandingan. Jakarta: Nusa Indah.

Susantio, D. (2011, March 21). Arkeologi Indonesia: Jejak Pudar di Goa Tengkorak. Harian Kompas.

Quirk, R, et.al. (1972). A Grammar of Contemporary English. Singapore: Longman.

Verhaar, J.W.M. (2004). Asas-Asas Linguistik Umum. Yogyakarta : Gadjah Mada University Press.

Yamaguchi, M. (1999). Penelusuran Bahasa Pitu Ulunna Salu Kedudukannya Dalam Penelitian Bahasa Di Sulawesi Selatan. Jurnal Analisis, Edisi Tahun III, 5.

Yamaguchi, M. (2012). Aspek-Aspek Bahasa Daerah di Sulawesi Bagian Selatan. Kyoto : Hokato Publishing Inc. 